THE RING 31, 2 (2009) DOI 10.2478/v10050-008-0055-5

\title{
OBSERVATIONS OF WATERBIRDS ON THE UPPER EUPHRATES DURING AUTUMN MIGRATION
}

\author{
Zbigniew Kasprzykowski, Artur Goławski and Cezary Mitrus
}

\begin{abstract}
Kasprzykowski Z., Goławski A., Mitrus C. 2009. Observations of waterbirds on the Upper Euphrates during autumn migration. Ring 31, 2: 79-84.

On 12-15 September 2004 we conducted a count of birds on a $68 \mathrm{~km}$ section of the Upper Euphrates, from the Atatürk dam to the town of Halfeti. Altogether 291 individuals from 30 waterbird species were noted, their density was 42.8 indiv. / $10 \mathrm{~km}$. Differentiation in numbers among particular trophic and morpho-ecological groups was significant. Within the trophic groups the phytophagous and ichthyophagous species were the most abundant. The most numerous within the morpho-ecological groups were the swimmers and flight feeders. Despite the lack of appropriate foraging places for some waterbird species, this part of the Euphrates plays an important role for autumn migration in this region. In comparison with other large Western Palearctic rivers, the Upper Euphrates showed low densities of birds and low species similarity.
\end{abstract}

Z. Kasprzykowski, Dept. of Ecology and Nature Protection, Univ. of Podlasie, Prusa 12, PL-08-110 Siedlce, Poland, E-mail: zbykas@ap.siedlce.pl; A. Goławski, C. Mitrus, Dept. of Zoology, Univ. of Podlasie, Prusa 12, PL-08-110 Siedlce, Poland.

Key words: waterbirds, Euphrates, autumn migration

\section{INTRODUCTION}

Turkey is placed in the middle of one of the most relevant Palearctic bird migration routes (Aslan and Kiziroğlu 2003). For many migrating waterbird species, valleys of larger rivers play an important role (Goławski and Kasprzykowski 2004), since they are used as ecological corridors during the autumn migration period. This is particularly accurate for the rivers with a north-south orientation. In Turkey some river parts that were turned into dam reservoirs have been objects of studies on both breeding and migrating bird communities (Karkaş and Kılış 2004, Perktaş and Ayaş 2005). The aim of this paper was to describe the waterbirds' community at the Upper Euphrates during the autumn migration period. 


\section{METHODS AND STUDY AREA}

Waterbirds were counted on a $68.4 \mathrm{~km}$ long transect along the Upper Euphrates (S Turkey), from the Atatürk dam $\left(37^{\circ} 28^{\prime} \mathrm{N}, 38^{\circ} 20^{\prime} \mathrm{E}\right)$ to the town of Halfeti $\left(37^{\circ} 12^{\prime} \mathrm{N}\right.$, $\left.37^{\circ} 52^{\prime} \mathrm{E}\right)$, located just before the dam in Birecik. In this region, the river was cascaded as a system of five dams: Keban, Karakaya, Atatürk, Birecik and Karkamis (Bobat 2004). The closer to the Birecik dam within the transect, the slower water speed and the larger reedbeds along the banks. The maximum river flow speed in Birecik Dam reaches $1900 \mathrm{~m}^{3} / \mathrm{s}$ (Bobat 2004). Birds were counted from 12 to 15 September 2004, between $10.00 \mathrm{a} . \mathrm{m}$. and $8.00 \mathrm{p} . \mathrm{m}$., from a canoe, with binoculars $10 \times 42$. We counted only non-passerines considered to be waterbirds or species related to riverbed or riverside habitats (hereafter called waterbirds for all the studied species). We investigated both the number of species and their abundance along the river. Additionally, birds were classified to the trophic and morpho-ecological groups according to Dobrowolski (1969) and Jakubiec (1978), respectively. Finally, we compared our data on richness and abundance with those found for other Western Palearctic rivers, such as the Volga in Russia (Goławski and Kasprzykowski 2004), the Vistula in Poland (Goławski and Kasprzykowski 2004), the Ili in Kasachstan (Dmoch and Goławski 1999) and the Dniestr in Ukraine (Goławski and Szynkarczyk 2000), during autumn migration. With this goal the index of species composition similarity between two samples was calculated according to the following formula (Sörensen 1948):

$$
Q S=[2 W /(A+B)] \times 100
$$

where:

$W$ - the number of species present in the two samples (common species),

$A$ - the number of species present only in A,

$B$ - the number of species present only in B.

Moreover, we calculated the index of densities similarity, for which the following formula, according to Wesołowski (1975), was used:

where:

$$
P Z=[2 C /(A+B)] \times 100
$$

$C$ - the sum of minimal values of densities for common species,

$A$ - the density of the community A,

$B$ - the density of the community B.

\section{RESULTS}

Altogether 291 individuals belonging to 30 species were counted (Table 1). The average density of all birds was 42.8 indiv. / $10 \mathrm{~km}$. The most common species were: the Yellow-legged Gull (Larus cachinnans) - 17.2\%, Teal (Anas crecca) - 13.1\%, Garganey (A. querquedula) - 10.9\% and White-winged Tern (Chlidonias leucopterus) - 10.6\%. Considering the trophic groups, the phytophagous (32\%), followed by the ichtyophagous (28\%), were the most numerous (Fig. 1). The differences in numbers noted among trophic groups were significant $\left(\chi^{2}=88.6\right.$, $\left.d f=4, p<0.001\right)$ and higher than 
the differences in number of species $\left(\chi^{2}=9.7 d f=4, p=0.046\right)$. The most numerous were swimmers (40\%), followed by flight-feeders (35\%), with significant differences among morpho-ecological groups $\left(\chi^{2}=167.3, d f=4, p<0.001\right.$, Fig. 1). Differences in number of species among particular morpho-ecological groups were non-significant $\left(\chi^{2}=5.0, d f=4, p=0.287\right)$.

Table 1

The numbers of individuals $(N)$, species domination $(D, \%)$, density (Dens, indiv. / $10 \mathrm{~km})$ and size of maximal flocks of birds (Max) on the Upper Euphrates. TROF - trophic groups: $\mathrm{E}$ - entomophagous, $\mathrm{F}$ - phytophagous, I - ichthyophagous, $\mathrm{P}$ - polyphagous, $\mathrm{R}$ - raptors; MORF - morpho-ecological groups: A - semi-aquatic waders, F - flight feeders, $\mathrm{G}$ - grassland and swamp birds, R - reed and bush birds, S - swimmers

\begin{tabular}{|l|c|c|c|c|c|c|}
\hline & TROF & MORF & N & D & Dens & Max \\
\hline Tachybaptus ruficollis & I & S & 18 & 6.2 & 2.6 & 11 \\
\hline Podiceps cristatus & I & S & 2 & 0.7 & 0.3 & 1 \\
\hline Ixobrychus minutus & I & R & 1 & 0.3 & 0.1 & 1 \\
\hline Nicticorax nicticorax & I & A & 10 & 3.4 & 1.5 & 2 \\
\hline Ardeola ralloides & I & A & 2 & 0.7 & 0.3 & 1 \\
\hline Egretta garzetta & I & A & 6 & 2.1 & 0.9 & 6 \\
\hline Ardea cinerea & I & A & 23 & 7.9 & 3.4 & 2 \\
\hline Ardea purpurea & I & A & 2 & 0.7 & 0.3 & 2 \\
\hline Anas crecca & F & S & 38 & 13.1 & 5.6 & 28 \\
\hline Anas platyrhynchos & F & S & 19 & 6.5 & 2.8 & 19 \\
\hline Anas acuta & F & S & 1 & 0.3 & 0.1 & 1 \\
\hline Anas querquedula & F & S & 32 & 10.9 & 4.7 & 19 \\
\hline Anas clypeata & F & S & 5 & 1.7 & 0.7 & 5 \\
\hline Aythya ferina & P & S & 3 & 1.0 & 0.4 & 3 \\
\hline Milvus migrans & R & F & 1 & 0.3 & 0.1 & 1 \\
\hline Circus aeruginosus & R & F & 1 & 0.3 & 0.1 & 1 \\
\hline Fulica atra & P & S & 1 & 0.3 & 0.1 & 1 \\
\hline Burhinus oedicnemus & E & G & 1 & 0.3 & 0.1 & 1 \\
\hline Gallinago gallinago & E & G & 5 & 1.7 & 0.7 & 3 \\
\hline Tringa totanus & E & G & 1 & 0.3 & 0.1 & 1 \\
\hline Tringa stagnatilis & E & G & 1 & 0.3 & 0.1 & 1 \\
\hline Tringa ochropus & E & G & 2 & 0.7 & 0.3 & 2 \\
\hline Actitis hypoleucos & E & G & 10 & 3.4 & 1.5 & 2 \\
\hline Larus ridibundus & P & F & 7 & 2.4 & 1.0 & 4 \\
\hline Larus cachinnans & P & F & 50 & 17.2 & 7.4 & 9 \\
\hline Gelochelidon nilotica & I & F & 2 & 0.7 & 0.3 & 1 \\
\hline Sterna hirundo & I & F & 1 & 0.3 & 0.1 & 1 \\
\hline Chlidonias leucopterus & E & F & 31 & 10.6 & 4.6 & 5 \\
\hline Alcedo atthis & I & R & 7 & 2.4 & 1.0 & 1 \\
\hline Ceryle rudis & I & F & 8 & 2.7 & 1.2 & 3 \\
\hline Total & - & $\mathbf{2 9 1}$ & $\mathbf{1 0 0}$ & $\mathbf{4 2 . 8}$ & - \\
\hline
\end{tabular}



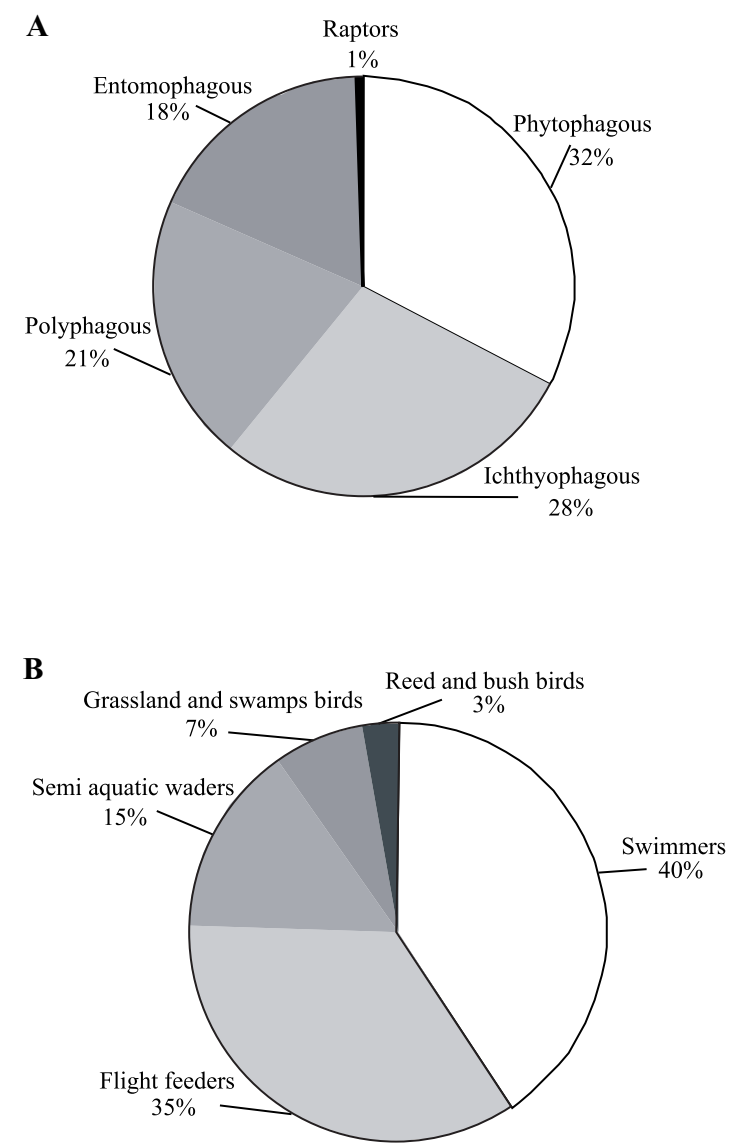

Fig. 1. Shares of individuals in trophic (A) and morpho-ecological (B) groups on the Upper Euphrates. $N=291$ birds.

\section{DISCUSSION}

On a transect along the Upper Euphrates, a total of 30 waterbird species were registered during four consecutive days within the autumn migration period. Among them, a high proportion of both swimmers and flight feeders were observed. It is likely that large riverbeds and slow current would allow good conditions for fish-eaters. By contrast, a low number of flat banks could explain an uncommon occurrence of grassland and swamp birds, often represented by waders (Charadriformes). Despite this, the study place seems to play a relevant role during the autumn migration period, as we found a higher number of species than in other similar habitats in Turkey. For instance, in the Dicle dam, located in the confluence of the Maden and Dibni rivers, only four species of waterbirds were observed (Karkaş and Kilış 2004). Also Perktaş and Ayaş (2005) observed a lower number of species on the Sariyar res- 
ervoir in NW Central Anatolia. In comparison with other large Western Palaeartic rivers, the Upper Euphrates showed a low species similarity. This low value was even more marked (i.e. lower) when the species density was included. The low densities of birds in the Euphrates valley might have influenced the low index values, which varied from $4.8 \%$ (compared to the Volga) to $18 \%$ (the Ili, Table 2). This was especially noticeable in the comparison of the Euphrates with the two larger rivers - the Volga and Vistula. On the other rivers (the Dnestr and Ili) the lower numbers of migrant species were recorded, and this fact may have influenced the relatively higher values of the index of densities similarity. With respect to the average of the bird numbers per $10 \mathrm{~km}$, the Euphrates valley was the poorest. This was connected with the lack of suitable feeding places preferred by many waterbird species. The low density of birds can be explained partially by a later study period in comparison with the other rivers and by the fact that the study was carried out at the end of the autumn passage for some species.

Table 2

Indices of species composition similarity $(Q S)$ and densities similarity $(P Z)$ between the Euphrates and the Volga, Vistula, Ili and Dnestr rivers

\begin{tabular}{|c|c|c|c|c|}
\hline \multirow{2}{*}{ Index } & $\begin{array}{c}\text { Volga } \\
45^{\circ} 16^{\prime} \mathrm{E}, 48^{\circ} 25^{\prime} \mathrm{N}\end{array}$ & $\begin{array}{c}\text { Vistula } \\
21^{\circ} 57^{\prime} \mathrm{E}, 51^{\circ} 25^{\prime} \mathrm{N}\end{array}$ & $\begin{array}{c}\text { Ili } \\
76^{\circ} 41^{\prime} \mathrm{E}, 44^{\circ} 19^{\prime} \mathrm{N}\end{array}$ & $\begin{array}{c}\text { Dnestr } \\
25^{\circ} 16^{\prime} \mathrm{E}, 48^{\circ} 19^{\prime} \mathrm{N}\end{array}$ \\
\hline$Q S$ & 50.6 & 40.6 & 48.1 & 48.1 \\
\hline$P Z$ & 4.8 & 6.5 & 18.0 & 17.9 \\
\hline
\end{tabular}

\section{ACKNOWLEDGEMENTS}

We extend special thanks to Ruth Sagehorn for providing comments that improved the quality of the manuscript and correcting the English.

\section{REFERENCES}

Aslan A., Kiziroğlu I. 2003. A study on the ornithofauna of Sakaryabaşı/Eminekin ponds and its vicinity. Turk. J. Zool. 27: 19-26.

Bobat A. 2004. Zebra Mussel and fouling problems in the Euphrates Basin. Turk. J. Zool. 28: 161-177.

Dmoch A., Goławski A. 1999. Der Herbstzug der Wasservögel im Tal des Ili (Kasachstan). Ornithol. Mitt. 51: 301-307.

Dobrowolski K.A. 1969. Structure of the occurrence of waterfowl types and morfo-ecological form. Ekol. Pol. A 17: 29-72.

Goławski A., Kasprzykowski Z. 2004. Comparison of bird fauna of the Volga and the Vistula rivers during autumn migration. Berkut 13: 103-109.

Goławski A., Szynkarczyk S. 2000. Early autumn observations of waterbirds on the middle Dnestr river in 1999. Berkut 9: 107-110.

Jakubiec Z. 1978: [Morpho-ecological differentiation of aquatic-swamp birds]. Wiad. Ekol. 24, 2: 99-107. (In Polish).

Karkaş and Kılış A. 2004. The birds of Dicle Dam (Diyarbakır). Turk. J. Zool. 28: 301-308. 
Perktaş U., Ayaş Z. 2005. Birds of Nallıhan Bird Paradise (central Anatolia, Turkey). Turk. J. Zool. 29: 45-59.

Sörensen T. 1948. A method of establishing groups of equal amplitude in plant sociology based on similarity of species content and its application to analyses of the vegetation on Danish commons. K. Dan. Vidensk. Selsk. Biol. Skr. 5: 1-34.

Wesołowski T. 1975. Birds of Lake Bytynskie. Acta orn. 15: 113-144. 